\title{
Initial performance of maize in response to NPK fertilization combined with Herbaspirillum seropedicae ${ }^{1}$
}

\author{
Marihus Altoé Baldotto², Lílian Estrela Borges Baldotto², Rogério Batista Santana ${ }^{3}$, Cláudio Roberto Marciano ${ }^{3}$
}

\begin{abstract}
The inoculation with plant growth-promoting bacteria can be a technological approach useful for increasing the production of maize. The objective of this study was to evaluate the initial performance of maize in response to application of doses of NPK combined with the inoculation of the diazotrophic bacteria Herbaspirillum seropedicae in an greenhouse experiment. The experiment consisted of six fertilizer levels: 0, 25, 50, 75, 100 and 200\% of the recommended dose of NPK applied to maize inoculated and non-inoculated with $H$. seropedicae. At 30 days after the treatment application, the growth characteristics and nutritional status of the plants were evaluated. Plant development was influenced by fertilization, but it was enhanced by combination with the bacteria, which resulted in significant increases in the dry mass of shoots (7\%) and leaf area (9\%) when compared with non-inoculated plants. The results showed increases in the concentration of $\mathrm{N}(11 \%), \mathrm{P}(30 \%)$ and $\mathrm{K}(17 \%)$ of maize plants in response to bacterial inoculation together with NPK compared with plants that were applied fertilize only. The greater consistency and stability response of the host plant to bacterization in the presence of chemical fertilizer indicate a promissory biotechnological approach for improving the initial growth and adaptation of maize to the cultivation environment.
\end{abstract}

Key words: Zea mays L., plant growth-promoting bacteria, nitrogen biological fixation, biofertilizer, biological feedstocks.

\section{RESUMO}

\section{Desempenho inicial do milho, em resposta à adubação NPK combinada com a inoculação de Herbaspirillum seropedicae}

A inoculação de bactérias promotoras de crescimento de plantas pode ser uma abordagem tecnológica útil para aumentar a produção de milho. O objetivo deste trabalho foi avaliar o desempenho inicial de plantas de milho, em resposta à aplicação de doses de NPK combinadas com a inoculação da bactéria diazotrófica Herbaspirillum seropedicae, em experimento em casa de vegetação. A matriz experimental consistiu em seis níveis de adubação: 0, 25, $50,75,100$ e $200 \%$ da dose de NPK recomendada, aplicados em plantas de milho inoculadas e não inoculadas com $H$. seropedicae. Aos 30 dias após a aplicação dos tratamentos, foram avaliadas as características de crescimento e nutricionais das plantas. $\mathrm{O}$ crescimento do milho foi influenciado pela adubação, mas foi reforçado pela combinação com a bactéria, que resultou em aumentos significativos na matéria seca da parte aérea (7\%) e área foliar (9\%), quando comparado com as das plantas não inoculadas. Os resultados indicaram incrementos no acúmulo de N (11\%), P (30\%)

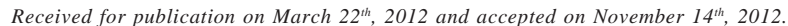

${ }^{1}$ Work partially funded by the Foundations for Research Support of the State of Rio de Janeiro (FAPERJ) and Minas Gerais (FAPEMIG).

${ }^{2}$ Agronomist Engineers, Doctors in Science. Instituto de Ciências Agrárias, Universidade Federal de Viçosa, Campus Florestal, Rodovia LMG 818, Km 06, 35690-000, Florestal, Minas Gerais, Brazil. marihus@ufv.br (corresponding author); lilian.estrela@ufv.br

${ }^{3}$ Agronomist Engineers. Centro de Ciências e Tecnologias Agropecuárias, Universidade Estadual do Norte Fluminense Darcy Ribeiro, Avenida Alberto Lamego, 2000, 28013-602, Campos dos Goytacazes, Rio de Janeiro, Brazil. marciano@uenf.br
} 
e K (17\%), em plantas de milho, em resposta à inoculação bacteriana em conjunto com NPK, quando comparado com os das plantas que apenas receberam adubação. A estabilidade e maior consistência da resposta da planta hospedeira para bacterização, na presença de fertilização química, apontam para uma ferramenta biotecnológica promissora para melhorar o crescimento inicial e adaptação de plantas de milho ao ambiente de cultivo.

Palavras-chave: Zea mays L., bactérias promotoras de crescimento de plantas, fixação biológica de nitrogênio, biofertilizantes, insumos biológicos.

\section{INTRODUCTION}

With the growing demand for increased yield in agriculture, also grows the demand for new technologies with less impact on natural resources. Among them, the use of micro-organisms promoters of plant growth may help or even meet the demand of nitrogen $(\mathrm{N})$ and phosphorus $(\mathrm{P})$ in different crops (Rodriguez \& Fraga, 1999; Baldani et al., 2009; Baldotto et al., 2010).

$\mathrm{N}$ and $\mathrm{P}$ are present in limiting concentrations in tropical soils and affect agricultural yield. Mineral fertilizers are used to meet the need of these nutrients. Although effective, mineral fertilizers have shown growing increase in production costs, mainly because they often require non-renewable raw materials and/or demand high energy costs for their production (Novais \& Mello, 2007).

Nitrogen exists in the soil system in many forms and changes (transforms) very easily from one form to another.

Because of nitrogen high mobility and transformations in the soil, the evaluation of its availability in the soil system is not commonly done by routine chemical analysis. Considering the important functions of this nutrient in the plant, such as protein synthesis, chlorophyll formation and alkaloid composition, among others, its low availability is synonymous with low yield. With respect to P, $90 \%$ of the analyses in the country show low levels of $\mathrm{P}$ available to crops, reaching less than $1 \mathrm{mg} \mathrm{dm}^{-3}$ by Mehlich-1 extractor. This low availability results in the high phosphate complexation on the surface of iron oxides $(\mathrm{Fe})$ and aluminum $(\mathrm{Al})$, which are predominant in the mineral fraction of tropical soils, in advanced stage of weathering, a factor that leads to applications of large amounts this nutrient in agriculture (Novais \& Mello, 2007).

Considering the acreage and the production volume, the maize crop is a major activity for Brazil's GDP. The production of the crop was approximately 55 million tons in 2010/11 and the planted area was about 13 million hectares (Brazil, 2012). Maize is one of the main export products and has an important role in human and animal nutrition, with great economic and social importance.
Moreover, it has growth potential because of the demand for energy of biofuels. However, in recent years this cereal acreage declined about $9 \%$, due to the negative balance between production cost and market prices (Brazil, 2012). For this reason, technologies that reduce production costs must be developed, including those that reduce spending on nutrients.

One possibility to minimize production costs of maize and make it more competitive, is the use of microorganisms that fix atmospheric $\mathrm{N}$ (termed diazotrophs), in similar way that successfully occurred with soybean in Brazil (Hungria et al. , 2005).

The biological nitrogen fixation was innovative and allowed Brazil to become the second largest producer of soybean. The same result can also be obtained from crops of the Poaceae family that includes maize and sugar cane (Baldani et al., 2009). In these grasses, unlike pulses, there is no formation of nodules and these microorganisms colonize from the surface to the interior of the plant tissue (termed endophytes and epiphytic), respectively (Hallmann et al. 1997; Baldotto \& Olivares, 2008).

For maize, the inoculation of the bacteria Azospirillum and Herbaspirillum brought positive results in the growth and development of plants (Baldani et al., 2009; Dotto et al., 2010; Pedrinho et al., 2010). However, there is little stability of the plant response to bacterization and the technology of diazotrophs needs to be adjusted to nonleguminous plants (Roesch, 2007).

In addition, there may be a continuum between forms of production, i.e., combinations of mineral nutrition and inoculation with growth promoting microorganisms to provide productions of maximum economic efficiency, or even the combined applications of these materials, providing technologies for more than one agriculture reality, eg, in terms of production costs and demand for the consumer market.

In this context, this study aimed to study the initial growth and mineral nutrition of maize (Zea mays L.) in response to application of NPK rates combined with the inoculation with the diazotrophic bacterium Herbaspirilum seropedicae. 


\section{MATERIALAND METHODS}

\section{Treatments and experiment conditions}

The experiment consisted of six fertilization levels: 0 , $25,50,75,100$ and $200 \%$ of the recommended dose of NPK (De-Polli et al., 1988) applied to maize plants, inoculated and non-inoculated with endophytic diazotrophic bacteria (Table 1). The experiment was conducted in a greenhouse in a completely randomized design with four replications, totaling 48 experimental units.

The experimental units consisted of a plastic/polythene vase of $1 \mathrm{dm}^{3}$, filled with subsurface horizon soil of a cohesive dystrophic Oxisol, of a depth of 40-80 cm, in Campos-RJ. The soil showed the following characteristics: Clay content $=$ $48 \% ; \mathrm{pH}=4.3 ; \mathrm{MOS}=3.33 \mathrm{dag} \mathrm{dm}^{-3} ; \mathrm{P}=1 \mathrm{mg} \mathrm{dm}^{-3} ; \mathrm{K}=101$ $\mathrm{mg} \mathrm{dm}{ }^{-3} ; \mathrm{Ca}^{2+}=0.30 \mathrm{cmolc} \mathrm{dm}^{-3} ; \mathrm{Mg}^{2+}=$ cmolc $0.30 \mathrm{dm}^{-3} ; \mathrm{Al}^{3+}$ $=0.80 \mathrm{cmolc} \mathrm{dm}^{-3} ; \mathrm{H}+\mathrm{Al}=3.20 \mathrm{cmolc} \mathrm{dm}^{-3} ; \mathrm{Na}=0.10 \mathrm{cmolc}$ $\mathrm{dm}^{-3} ; \mathrm{SB}=0.96 \mathrm{cmolc} \mathrm{dm}^{-3} ; \mathrm{t}=1.76 \mathrm{cmolc} \mathrm{dm}^{-3} ; \mathrm{T}=4.16 \mathrm{cmolc}$ $\mathrm{dm}^{-3} ; \mathrm{V}=23 \%$ and $\mathrm{m}=45 \%$. Measurements followed the recommendations of Silva (2009).

Liming was performed 30 days before sowing, according to the recommended fertilization guidelines, using the criterion of aluminum neutralization and increased availability of $\mathrm{Ca}$ and $\mathrm{Mg}$ (Alvarez \& Ribeiro, 1999). The soil of each experimental unit was placed in plastic bags, along with lime, homogenized and moistened to field capacity. After incubation, fertilization was carried out in each experimental unit. The 04-14-08 NPK fertilizer was homogenized with the soil in plastic bags at the rates shown in Table 1. Then, the soil of each treatment was added to a plastic container in which six were sowed maize seeds, and 5 days after emergence the seedlings were thinned, leaving two plants per pot.
The inoculum was obtained by growing Herbaspirilum seropedicae HIII 206 in DYGS liquid medium (Döbereiner et al. 1,995) under constant shaking at $120 \mathrm{rpm}$ for 24 hours at $30^{\circ} \mathrm{C}$. The bacterial suspensions were adjusted for cell number of 108 cells $\mathrm{mL}^{-1}$. The inoculation was performed ten days after seeding, by adding $3 \mathrm{~mL}$ of inoculum with an automatic pipette, on the surface of the soil and at the collar of the maize plants (genotype UENF 506-8) bearing three leaves.

\section{Morphological analyses}

At 30 days after germination, the plants were collected for measurement of the following variables: number of leaves (NL), plant height (ALT) measured by the distance of the plant collar up the sheath of the first fully expanded leaf, using a graduate ruller; length of the largest fully expanded leaf (CFE); stem diameter (DC), using a Starret 727 digital caliper; leaf area (LA), using a bench top LI3100 leaf area meter (LICOR, USA); root fresh matter (MFR); shoot fresh matter (MFPA); root dry matter (MSR) and shoot dry matter (MSPA) in an forced air oven at $60{ }^{\circ} \mathrm{C}$ for 7 days. After weighing, the root dry matter and shoot dry matter ratio (RPA) was calculated.

The SPAD index, which estimates the amount of chlorophyll through the green color intensity was determined using a portable SPAD-502 (Minolta, Japan) chlorophyll meter, 30 days after germination.

\section{Nutrient analysis}

After drying, the maize shoots were ground in Wiley mill, with sieves of $0.25 \mathrm{~mm}$ ( $60 \mathrm{mesh}$ ). Then, the material was crushed, sieved, digested with sulfuric acid and

Table 1. Treatments combined with the factors under study

\begin{tabular}{|c|c|c|c|c|}
\hline \multirow{2}{*}{ Treatments $^{(1)}$} & \multicolumn{2}{|c|}{ NPK $^{(2)}$} & NPK amount ${ }^{(3)}$ & \multirow{2}{*}{$\frac{\text { Lime amount }^{4)}}{\mathrm{g} / \text { vase }}$} \\
\hline & $\%$ & $\mathrm{~kg} \mathrm{ha}^{-1}$ & $\mathrm{~g} /$ vase & \\
\hline NPK0 & 0 & 0 & 0,00 & 1,36 \\
\hline NPK25 & 25 & 161 & 3,21 & 1,36 \\
\hline NPK50 & 50 & 321 & 6,43 & 1,36 \\
\hline NPK75 & 75 & 482 & 9,64 & 1,36 \\
\hline NPK100 & 100 & 643 & 12,86 & 1,36 \\
\hline NPK200 & 200 & 1.286 & 25,71 & 1,36 \\
\hline NPK0+B & 0 & 0 & 0,00 & 1,36 \\
\hline NPK25+B & 25 & 161 & 3,21 & 1,36 \\
\hline NPK50+B & 50 & 321 & 6,43 & 1,36 \\
\hline NPK75+B & 75 & 482 & 9,64 & 1,36 \\
\hline NPK100+B & 100 & 643 & 12,86 & 1,36 \\
\hline NPK200+B & 200 & 1.286 & 25,71 & 1,36 \\
\hline
\end{tabular}

(1) Treatments: NPK 0, 25, 50, 75, 100 and $200 \%$ of the dose recommended for cultivation of maize (De-Polli et al. 1988); B = inoculation of Herbaspirillum seropedicae. ${ }^{(2)}$ NPK $=04-14-08$ formulation. ${ }^{(3)}$ Quantity of NPK applied according to the fertilizer recommendation, considering requirement for phosphorus of $90 \mathrm{~kg} \mathrm{ha}^{-1}$ of $\mathrm{P}_{2} \mathrm{O}_{5}$ by the chemical soil analysis in Table 2. For example: to apply $100 \%$ of the recommended dose, it was calculated $643 \mathrm{~kg} \mathrm{ha}^{-1}$ of NPK 04-14-08 and considering a final population of 50,000 plants ha ${ }^{-1}$, this dose was equivalent to $12.86 \mathrm{~g} / \mathrm{pot}^{(4)}$ Amount of lime applied according to the liming requirement of $2.7 \mathrm{Mg} \mathrm{ha}^{-1}$, according to Alvarez \& Ribeiro (1999). 
hydrogen peroxide, and total $\mathrm{N}, \mathrm{P}, \mathrm{K}, \mathrm{Ca}$ and $\mathrm{Mg}$ were determined (Silva, 2009). N was determined by the method of Nessler. P was determined using molecular absorption spectrophotometer (colorimetry) at a wavelength of 725 $\mathrm{nm}$. The determination of $\mathrm{K}$ was made by flame photometry. $\mathrm{Ca}$ and $\mathrm{Mg}$ were measured by atomic absorption spectrophotometry. The contents of $\mathrm{N}, \mathrm{P}, \mathrm{K}, \mathrm{Ca}$ and $\mathrm{Mg}$ were calculated by multiplying the dry mass of shoots (kg) by the content $\left(\mathrm{g} \mathrm{kg}^{-1}\right)$ of the nutrient considered.

\section{Count of diazotrophs}

Counting of bacteria was carried out using the Most Probable Number (MPN), described by Döbereiner et al. (1995). Samples of $1 \mathrm{~g}$ of root macerate were washed in 9 $\mathrm{mL}$ of saline solution and serial dilutions were made up to $10^{-7}$. Then, a $0.1 \mathrm{~mL}$ aliquot of each dilution was added to vials containing $5 \mathrm{~mL}$ of semisolid $\mathrm{JNFb}$ medium. The flasks were incubated for seven days at $30{ }^{\circ} \mathrm{C}$. The count of bacteria was estimated by referring to the table of McCrady, for three replicates per dilution. It was considered positive growth the formation of an aerotactic band on the surface of the medium.

\section{Statistical analyzes}

Results were subjected to analysis of variance and the effects of treatments for qualitative variable, were unfolded into mean contrasts (Alvarez \& Alvarez, 2006). For the quantitative factors, regression equations between the means of the variables and levels of NPK with and without inoculation of bacteria (obtaining response curves) were adjusted. The application of the $\mathrm{F}$ test in the unfolding of the factors was performed at 1, 5 and $10 \%$ probability. In the regression analysis, the models were tested when having coefficient of determination greater than 0.65 . The regression equations were used to determine the level of fertilizer in the absence and presence of bacterial inoculum, to achieve maximum physical efficiency of dry matter production of maize shoots, calculated from the derived regression equation to determine the maximum point of the response curve in both the absence and in the presence of bacteria. The rate values for maximum efficiency were substituted in the regression equations for each of the other variables in order to estimate them for this condition.

\section{RESULTS}

\section{Growth of shoots}

The analysis of growth of shoots indicated, in general, positive effect of treatments that combined NPK mineral fertilizer with the growth-promoting bacteria Herbaspirillum seropedicae compared with the use of only fertilizers. Table 2 shows that the bacterial inoculation with fertilizer resulted in plants with significant increments of 3, 4, 9, 7 and $9 \%$ in the variables height, length of leaf, mass of fresh matter of shoots, mass of dry matter of shoots and leaf area. The stem diameter was an exception, decreasing by $2 \%$ with the use of bacteria combined with chemical fertilizers.

Table 3 shows the regression equations, adjusted between the mean growth characteristics (dependent variables, y) of maize and levels of NPK in the absence and presence of inoculated bacteria (independent variable, $\mathrm{x})$. Among the regression equations of Table 3, it is observed in the penultimate variable, the response curve of dry matter of shoots (MSPA), which was used to obtain the maximum rates of physical efficiency (MEF), i.e., rates that reflected higher mass accumulation in plants. For the unfolding of NPK and NPK $+\mathrm{B}$, both MEF levels were $200 \%$ of the demand for fertilization, resulting in MSPA equal to 1.90 and $2.18 \mathrm{~g}$ per plant, respectively. It is worth noting also that when the variation in the growth of the treated plants showed a coefficient of determination R2 $<0.65$, the estimation was represented by the mean $(\hat{y}=\bar{y})$ rates of NPK combined or not with the application of bacterial growth promoters. Generally, the shape of the quadratic response was observed both in the presence and absence of bacterial inoculum combined with the mineral fertilizer.

Substituting the means of levels of NPK and NPK + B, on the condition of maximum physical efficiency of MSPA, in the regression equations of Table 3 , we obtained the means of the other variables of growth of shoots. These means determined for the condition of maximum efficiency, were used to obtain the relative differences between the treatments NPK and NPK + B and the control treatment, using the equation: Relative Increments $(\%)=[($ mean of treatment - mean of control)/mean of control] x 100.

All differences observed marked increases over the control. For variables NF, ALT, DC, DFE, MFPA, MSPA and $\mathrm{AF}$, there were increments of 4 and $8 \% ; 3$ and $17 \% ; 15$ and $22 \% ; 10$ and $11 \% ; 35$ and $97 \% ; 34$ and $74 \%$ and of $35 \%$ and $85 \%$, of the treatments NPK and NPK + B over the control, respectively.

It was found that the estimated relative increments were higher for treatments that received mineral fertilization together with bacterial inoculation $(\mathrm{NPK}+\mathrm{B})$ in comparison with the treatments that received only mineral fertilizer (NPK) in all studied variables.

\section{Growth of the root system}

The data of root growth was analyzed in a similar way to the data of growth of shoots and the means and the regression equations are shown in Tables 4 and 5, respectively. The results revealed that root growth varied according to the levels of NPK in both the absence and in 
the presence of inoculum, without, on average, significant contrast for the comparison with or without inoculation (B ${ }^{-}$vs. $B^{+}$).

Table 5 also reveals a lack of adjustment of regression models between most variables of root growth and levels of NPK, i.e., there was little effect of mineral fertilizer levels on the plant root system. However, the relationship between root and shoot decreased $85 \%$, with the application of increasing rates of NPK, combined or not with bacterization.

\section{Nutritional status}

On average, the contents of N, P and K (Table 6) increased with the application of bacteria together with

Table 2. Characteristics of growth of shoots of 30-old-day maize plants in response to fertilization with NPK combined or not with inoculation of the growth promoting bacteria Herbaspirillum seropedicae; mean contrast; relative increase (IR), mean square error (QMR) and coefficient of variation (CV)

\begin{tabular}{|c|c|c|c|c|c|c|c|}
\hline \multirow{3}{*}{ Treatments ${ }^{(1)}$} & \multicolumn{7}{|c|}{ Characteristics of growth of shoot ${ }^{(4)}$} \\
\hline & \multirow{2}{*}{ NF } & ALT & CFE & \multirow{2}{*}{$\begin{array}{c}\text { DC } \\
\mathrm{mm}\end{array}$} & MFPA & MSPA & \multirow{2}{*}{$\frac{\mathbf{A F}}{\mathrm{cm}^{2}}$} \\
\hline & & \multicolumn{2}{|c|}{$\mathrm{cm}$} & & \multicolumn{2}{|c|}{$\mathrm{g}$} & \\
\hline NPK0 & 5,75 & 45,75 & 42,10 & 5,17 & 8,58 & 1,25 & 286,67 \\
\hline NPK25 & 5,63 & 43,38 & 44,80 & 5,24 & 8,65 & 1,38 & 290,06 \\
\hline NPK50 & 5,50 & 40,25 & 41,70 & 4,99 & 7,83 & 1,20 & 291,56 \\
\hline NPK75 & 5,75 & 42,13 & 44,00 & 5,52 & 9,05 & 1,38 & 319,31 \\
\hline NPK100 & 6,13 & 50,88 & 45,70 & 5,18 & 10,68 & 1,58 & 342,74 \\
\hline NPK200 & 6,00 & 47,25 & 49,50 & 5,72 & 13,25 & 1,90 & 438,58 \\
\hline NPK0+B & 6,00 & 45,00 & 45,10 & 4,70 & 7,93 & 1,25 & 280,88 \\
\hline NPK25+B & 5,63 & 40,50 & 40,70 & 4,82 & 7,90 & 1,18 & 274,13 \\
\hline NPK50+B & 5,75 & 43,38 & 45,70 & 5,25 & 10,23 & 1,45 & 345,97 \\
\hline NPK75+B & 5,63 & 47,50 & 45,00 & 5,31 & 10,65 & 1,60 & 343,89 \\
\hline NPK100+B & 6,00 & 49,00 & 47,70 & 5,22 & 10,68 & 1,60 & 358,60 \\
\hline NPK200+B & 6,25 & 52,50 & 53,60 & 5,95 & 15,73 & 2,18 & 533,96 \\
\hline Contraste $\mathrm{B}^{-} v s . \mathrm{B}^{+(2)}$ & $0,08^{\mathrm{ns}}$ & $1,38^{*}$ & $1,67 *$ & $-0,09 *$ & $0,85 * *$ & $0,10 * *$ & $28,08 * *$ \\
\hline $\operatorname{IR}(\%)^{(3)}$ & 1 & 3 & 4 & 2 & 9 & 7 & 9 \\
\hline QMR & 0,13 & 31,43 & 22,49 & 0,18 & 4,12 & 0,08 & 3899,31 \\
\hline$\overline{\mathrm{CV}(\%)}$ & 6,19 & 12,30 & 10,40 & 8,07 & 20,05 & 18,96 & 18,19 \\
\hline
\end{tabular}

(1) Treatment: $0,25,50,75,100$ and $200 \%$ of the recommended NPK dose; B = inoculation of Herbaspirillum seropedicae. (2) Contrast: $\mathrm{B}^{-}=$no inoculation; $\mathrm{B}^{+}=$inoculation. ${ }^{(3)}$ Relative increase: $100(\mathrm{xy}) / \mathrm{y}$, where $\mathrm{x}$ is the mean of the highest value and $\mathrm{y}$ the mean of the treatment with the lowest value. ${ }^{(4)}$ Characteristics of growth of the shoot: NF = number of leaves; ALT = plant height $(\mathrm{cm})$; DC $=$ stem diameter $(\mathrm{mm}) ; \mathrm{CFE}=$ fully expanded leaf length $(\mathrm{cm}) ;$ MFPA = fresh matter mass of shoots $(\mathrm{g})$; MSPA = dry mass of shoots $(\mathrm{g}) ;$ AF $=$ leaf area $(\mathrm{cm} 2) .{ }^{n{ }^{*}}$ and ${ }^{* *}=$ not significant at $10 \%$ and significant at $5 \%$ and $1 \%$ probability level by the $\mathrm{F}$ test, respectively.

Table 3. Regression equations of the characteristics growth of shoots of 30-day-old maize plants, in response to application of NPK doses combined, or not, with inoculation of the growth promoting bacteria Herbaspirillum seropedicae

\begin{tabular}{|c|c|c|c|}
\hline Variable $^{(1)}$ & Unfolding & Regression equations & $\mathbf{R}^{2}$ \\
\hline \multirow[t]{2}{*}{$\mathrm{NF}$} & NPK & $\hat{\mathrm{y}}=\overline{\mathrm{y}}=5,80$ & \\
\hline & $\mathrm{NPK}+\mathrm{B}$ & $\hat{y}=5,866-0,003 x+0,00003^{(P<0,16)} x^{2}$ & 0,656 \\
\hline \multirow[t]{2}{*}{ ALT } & NPK & $\hat{\mathrm{y}}=\overline{\mathrm{y}}=44,95$ & \\
\hline & $\mathrm{NPK}+\mathrm{B}$ & $\hat{y}=42,470+0,049 x+0,00001 * * x^{2}$ & 0,746 \\
\hline \multirow[t]{2}{*}{ DC } & NPK & $\hat{\mathrm{y}}=\overline{\mathrm{y}}=5,30$ & \\
\hline & $\mathrm{NPK}+\mathrm{B}$ & $\hat{y}=4,724+0,007 x-0,00001^{\circ} x^{2}$ & 0,924 \\
\hline \multirow[t]{2}{*}{ CFE } & NPK & $\hat{y}=42,630+0,012 x+0,0001 * x^{2}$ & 0,811 \\
\hline & $\mathrm{NPK}+\mathrm{B}$ & $\hat{y}=43,410+0,014 x+0,0001 * x^{2}$ & 0,827 \\
\hline \multirow[t]{2}{*}{ MFPA } & NPK & $\hat{y}=8,289+0,005 x+0,0001 * x^{2}$ & 0,906 \\
\hline & $\mathrm{NPK}+\mathrm{B}$ & $\hat{y}=7,821+0,029 x+0,00005 * x^{2}$ & 0,960 \\
\hline \multirow[t]{2}{*}{ MSPA } & NPK & $\hat{y}=1,2497+0,0013 x+0,00001 * x^{2}$ & 0,888 \\
\hline & $\mathrm{NPK}+\mathrm{B}$ & $\hat{\mathrm{y}}=1,1946+0,0041 \mathrm{x}+0,000004 * * \mathrm{x}^{2}$ & 0,957 \\
\hline \multirow[t]{2}{*}{$\mathrm{AF}$} & NPK & $\hat{y}=282,2+0,280 x+0,002 * * x^{2}$ & 0,988 \\
\hline & $\mathrm{NPK}+\mathrm{B}$ & $\hat{\mathrm{y}}=278,0+0,614 \mathrm{x}+0,003 * * \mathrm{x}^{2}$ & 0,966 \\
\hline
\end{tabular}

\footnotetext{
(1) Variable: NF = number of leaves; ALT = plant height $(\mathrm{cm})$; DC = stem diameter $(\mathrm{mm})$; CFE = fully expanded leaf length $(\mathrm{cm})$; MFPA =
} fresh matter mass of shoots $(\mathrm{g})$; MSPA $=$ dry mass of shoots $(\mathrm{g}) ; \mathrm{AF}=$ leaf area $(\mathrm{cm} 2) .{ }^{* *},{ }^{*},{ }^{\circ}$ and ${ }^{\mathrm{P}}=$ significant at 1,5 , and $10 \%$ probability. 
the fertilizer, with increments of 11,30 and $17 \%$, respectively, compared with treatments receiving only mineral fertilizer. For $\mathrm{Ca}, \mathrm{Mg}$, on the other hand, there was no effect of bacteria application. The SPAD index decreased by $4 \%$ with inoculation.

It was found that most of the variables showed significant increase by inoculating Herbaspirillum seropedicae together with NPK (Tables 6 and 7).

Substituting the values of the levels of NPK and $\mathrm{NPK}+\mathrm{B}$, in the physical condition of maximum efficiency of MSPA, in the regression equations of Table 7, provided the values of the nutritional content of maize plants, which, in turn, were used to estimate the relative increments compared with the control treatments. The increments of treatments containing NPK and NPK + B over the controls were 41 and $24 \%$ for $\mathrm{N} ; 59$ and $190 \%$ for $\mathrm{P}, 47 \%$ and $84 \%$ for $\mathrm{K} ; 50$ and $12 \%$ for $\mathrm{Ca} ; 22$ and $55 \%$ for $\mathrm{Mg} ; 3$ and 0 for SPAD, respectively.

\section{Bacterial Count}

We observed an increased number of diazotrophs in the roots of plants from seeds inoculated with

Table 4. Characteristics of root growth of 30-day-old maize plants in response to the application of NPK doses combined or not with inoculation of the growth promoting bacteria Herbaspirillum seropedicae; mean contrast; relative increase (IR), mean square error (QMR) and coefficient of variation (CV))

\begin{tabular}{lccc}
\hline & \multicolumn{3}{c}{$\begin{array}{c}\text { Characteristics } \\
\text { of growth of } \text { root }^{(4)}\end{array}$} \\
\cline { 2 - 4 } Treatments $^{(\mathbf{1})}$ & MFR & MSR & RPA \\
\cline { 2 - 4 } & \multicolumn{3}{c}{$\mathrm{g}$} \\
\hline NPK0 & 11,15 & 1,53 & 1,22 \\
NPK25 & 11,23 & 1,10 & 0,80 \\
NPK50 & 13,43 & 1,23 & 1,02 \\
NPK75 & 14,08 & 1,13 & 0,82 \\
NPK100 & 14,36 & 1,20 & 0,76 \\
NPK200 & 13,73 & 1,25 & 0,66 \\
NPK0+B & 11,39 & 1,15 & 0,92 \\
NPK25+B & 12,19 & 1,10 & 0,94 \\
NPK50+B & 15,01 & 1,30 & 0,90 \\
NPK75+B & 12,73 & 1,08 & 0,67 \\
NPK100+B & 12,50 & 1,15 & 0,72 \\
NPK200+B & 13,97 & 1,30 & 0,60 \\
Contraste B $v s . B^{+(2)}$ & $-0,53^{\mathrm{ns}}$ & $-0,06^{\mathrm{ns}}$ & $-0,61^{\mathrm{ns}}$ \\
IR (\%) ${ }^{(3)}$ & 4 & 5 & 1 \\
QMR & 4,19 & 0,08 & 0,11 \\
\hline CV (\%) & 15,49 & 23,60 & 18,30 \\
\hline
\end{tabular}

(1) Treatment: 0, 25, 50,75, 100 and 200\% of the recommended NPK dose; B = inoculation of Herbaspirillum seropedicae. ${ }^{(2)}$ Contrast: $\mathrm{B}^{-}=$no inoculation; $\mathrm{B}^{+}=$inoculation. ${ }^{(3)}$ Relative increase: $100(\mathrm{xy}) / \mathrm{y}$, where $\mathrm{x}$ is the mean of the highest value and $\mathrm{y}$ the mean of the treatment with the lowest value. ${ }^{(4)}$ Characteristics of root growth: MFR = root fresh matter; MSR = root dry matter; RPA = root/shoot ratio (dry matter). ${ }^{n s^{*}}=$ not significant at $10 \%$ probability level by the F test.
Herbaspirillum seropedicae when compared with noninoculated plants (Figure 1), confirming the effect of bacterization.

The most probable number (MPN) of bacteria showed that the fertilization interfered in the population of diazotrophs of the inoculated plants. The increasing levels of NPK caused an increase in bacteria inoculated and then a stabilization, followed by the fall in the population. Thus, the largest populations were found in plants inoculated that received 25 to $75 \%$ NPK (Figure 1).

\section{DISCUSSION}

There inoculation of Herbaspirillum seropedicae together with NPK promoted growth of shoots and improved the mineral nutrition of maize plants as compared to applying only chemical fertilizers. The positive effects of inoculation with $H$. seropedicae on the host plant, although not yet fully elucidated, can be attributed to biological fixation of atmospheric nitrogen (Urquiaga et al., 1992), phosphate solubilization (Pedrinho et al., 2010), synthesis of phytohormones (Radwan et al., 2004) and production of ACC deaminase (Rothballer et al. 2008).

In this study, no significant differences were observed in dry matter accumulation in roots of maize in response to application of NPK rates combined or not with the inoculation of $H$. seropedicae. It was found that with increasing doses of fertilizers, there was a decrease in the root/shoot ratio, confirming the increased availability of nutrients in the root environment.

In studies of inoculation with bacteria that promote plant growth without application of fertilizers, root growth was due mainly to the increased emission of root hairs, promoted by auxin stimuli secreted by the bacteria (Dobbelaere et al. 1999; Radwan et al. 2004). In this work, $H$. seropedicae stimulated the accumulation of nutrients in the shoots of maize plants, probably because of the greater nutrient uptake by roots. Increments of $30 \%$ in P content, in the level of fertilization of maximum physical efficiency, with inoculation of $H$. seropedicae, for example, can be attributed to the stimulus of the root formation in the presence of bacteria, which would result in higher P uptake by root interception. Increasing the root surface would, also, result in a greater absorption of $\mathrm{P}$ arising from transport mechanisms, diffusion and mass flow (Novais \& Mello, 2007). Although this hypothesis can not be confirmed in this study, the use of bacteria, acting as $H$. seropedicae, was able to improve the efficiency of absorption and accumulation of P. Since much of phosphatic fertilizers recommended from nonlabile P (Mello \& Novais, 2007), the bacterial inoculation could promote economic efficiency in the use of the fertilizer. 
The increases in the contents of $\mathrm{N}$ and $\mathrm{K}$ in the plants inoculated with $H$. seropedicae can also be explained by the increased absorption of these nutrients in the root environment. Moreover, for $\mathrm{N}$, the supposed positive effects of atmospheric nitrogen fixation by $H$. seropedicae are added up (Baldani et al., 2009; Dotto et al., 2010). Notably, the inoculation of $H$. seropedicae in maize increases yield and reduces the amount of nitrogen fertilizer required by the crop (Reis et al., 2009). However, the effect can be negative because it is dependent on the maize genotype (Dotto et al., 2010).

The MPN of diazotrophs showed that the fertilizer in small doses favors an increase in the bacterial population inoculated, and levels of 25 to $75 \%$ of NPK favored a greater permanence of inoculum in the root environment. The structural events involved in the interaction between $H$. seropedicae-host plant have been well described for different cultures (Baldotto et al., 2011) and can be summarized in the steps: adhesion, anchoring, infection and colonization. The initial events of the interaction are dependent on a rhizosphere environment favorable to bacterial growth, including various factors such as moisture and nutrient availability. In this study, for the best efficiency of bacterization, the ideal would be to use levels of up to $75 \%$ NPK.

The instability of the host plant response to inoculation with growth-promoting bacteria is an obstacle for the expansion and consolidation of the use

Table 5. Regression equations for the characteristics of root growth of 30-day-old maize plants in response to fertilization with NPK doses combined, or not, with inoculation of the growth promoting bacteria Herbaspirillum seropedicae

\begin{tabular}{llll}
\hline Variable $^{(1)}$ & Unfolding & Regression equations & $\mathbf{R}^{2}$ \\
\hline MFR & NPK & $\hat{y}=\bar{y}=13,50$ \\
& NPK + B & $\hat{y}=\bar{y}=12,97$ \\
MSR & NPK & $\hat{y}=\bar{y}=1,24$ \\
& NPK + B & $\hat{y}=\bar{y}=1,18$ & 0,688 \\
RPA & NPK & $\hat{y}=1,126-0,005 x+0,00001^{\circ} x^{2}$ & 0,818 \\
& NPK + B & $\hat{y}=0,967-0,003 x+0,000007^{\circ} \mathrm{x}^{2}$ & \\
\hline
\end{tabular}

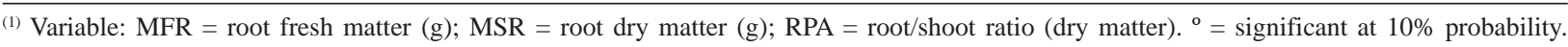

Table 6. Nutritional characteristics of 30-day-old maize plants in response to application of NPK doses combined with inoculation of the growth promoting bacteria Herbaspirillum seropedicae; mean contrast; relative increase (IR), mean square error (QMR) and coefficient variation $(\mathrm{CV})$

\begin{tabular}{|c|c|c|c|c|c|c|}
\hline \multirow{3}{*}{ Treatments $^{(1)}$} & \multicolumn{6}{|c|}{ Nutritional characteristics $^{(4)}$} \\
\hline & $\mathbf{N}$ & $\mathbf{P}$ & $\mathbf{K}$ & $\mathbf{C a}$ & Mg & \multirow{2}{*}{ SPAD } \\
\hline & \multicolumn{5}{|c|}{$\mathrm{mg} /$ planta } & \\
\hline NPK0 & 9,57 & 1,83 & 8,85 & 0,15 & 0,28 & 17,25 \\
\hline NPK25 & 10,98 & 2,60 & 13,75 & 0,21 & 0,28 & 15,42 \\
\hline NPK50 & 10,16 & 2,35 & 8,91 & 0,17 & 0,23 & 16,22 \\
\hline NPK75 & 11,11 & 3,21 & 11,11 & 0,23 & 0,32 & 17,30 \\
\hline NPK100 & 15,69 & 4,33 & 13,14 & 0,25 & 0,37 & 15,15 \\
\hline NPK200 & 16,26 & 4,46 & 16,68 & 0,30 & 0,36 & 17,85 \\
\hline NPK0+B & 11,28 & 2,64 & 11,17 & 0,19 & 0,27 & 14,83 \\
\hline NPK25+B & 8,18 & 2,14 & 10,50 & 0,19 & 0,26 & 15,20 \\
\hline NPK50+B & 15,37 & 3,20 & 11,87 & 0,25 & 0,34 & 17,33 \\
\hline NPK75+B & 13,47 & 4,27 & 14,18 & 0,24 & 0,33 & 17,63 \\
\hline NPK100+B & 10,96 & 4,62 & 16,80 & 0,25 & 0,35 & 15,33 \\
\hline NPK200+B & 22,83 & 7,63 & 20,39 & 0,31 & 0,43 & 15,23 \\
\hline Contraste $\mathrm{B}^{-} v s . \mathrm{B}^{+(2)}$ & $1,39^{* *}$ & $0,95^{* *}$ & $2,08^{* *}$ & $0,02^{\text {ns }}$ & $0,02^{\mathrm{ns}}$ & $-0,61^{* *}$ \\
\hline $\operatorname{IR}(\%)^{(3)}$ & 11 & 30 & 17 & 10 & 7 & 4 \\
\hline QMR & 3,66 & 0,45 & 1,95 & 0,001 & 0,002 & 2,74 \\
\hline $\mathrm{CV}(\%)$ & 29,06 & 36,32 & 21,25 & 29,17 & 27,03 & 11,13 \\
\hline
\end{tabular}


of this new technology (Baldani et al., 2009). To minimize this problem, alternatives such as adequacy of inoculation vehicles and the management of the rhizospheric environment should be sought (Bucher \&
Reis, 2008). Within this context, this study indicates the possibility of adequate rates of chemical fertilizers that provides increases in bacterial colonization and performance.

Table 7. Regression equations for the nutritional characteristics of 30-day-old maize plants in response to fertilization with NPK doses combined, or not, with inoculation of the growth promoting bacteria Herbaspirillum seropedicae

\begin{tabular}{|c|c|c|c|}
\hline Variable $^{(1)}$ & Unfolding & Regression equations & $\mathbf{R}^{2}$ \\
\hline \multirow{2}{*}{$\mathrm{N}$} & NPK & $\hat{\mathrm{y}}=9,199+0,050 \mathrm{x}-0,00007^{\circ} \mathrm{x}^{2}$ & 0,782 \\
\hline & $\mathrm{NPK}+\mathrm{B}$ & $\hat{y}=11,00-0,005 x+0,0001^{\circ} x^{2}$ & 0,757 \\
\hline \multirow{2}{*}{$\mathrm{P}$} & NPK & $\hat{y}=1,728+0,027 x-0,00007^{*} x^{2}$ & 0,874 \\
\hline & $\mathrm{NPK}+\mathrm{B}$ & $\hat{y}=2,243+0,019 x+0,00004 * * x^{2}$ & 0,965 \\
\hline \multirow{2}{*}{ K } & NPK & $\hat{\mathrm{y}}=\overline{\mathrm{y}}=12,07$ & \\
\hline & $\mathrm{NPK}+\mathrm{B}$ & $\hat{y}=10,11+0,056 x-0,00002 x^{2}$ & 0,935 \\
\hline \multirow{2}{*}{$\mathrm{Ca}$} & NPK & $\hat{y}=0,157+0,001 x-0,000001 * x^{2}$ & 0,859 \\
\hline & $\mathrm{NPK}+\mathrm{B}$ & $\hat{y}=0,187+0,0001 x-0,000001 * * x^{2}$ & 0,902 \\
\hline \multirow{2}{*}{$\mathrm{Mg}$} & NPK & $\hat{y}=\bar{y}=0,31$ & \\
\hline & $\mathrm{NPK}+\mathrm{B}$ & $\hat{\mathrm{y}}=0,262+0,001 \mathrm{x}-0,000001 * * \mathrm{x}^{2}$ & 0,911 \\
\hline \multirow{2}{*}{ SPAD } & NPK & $\hat{\mathrm{y}}=\overline{\mathrm{y}}=16,53$ & \\
\hline & $\mathrm{NPK}+\mathrm{B}$ & $\hat{\mathrm{y}}=\overline{\mathrm{y}}=15,92$ & \\
\hline
\end{tabular}

(1) Variable: nutrient content: $\mathrm{N}, \mathrm{P}, \mathrm{K}, \mathrm{Ca}, \mathrm{Mg}=$ nitrogen, phosphorus, potassium, calcium, magnesium, respectively $(\mathrm{mg} / \mathrm{plant}) .{ }^{* *},{ }^{*},{ }^{\circ}=$ significant at 1,5 and $10 \%$ probability.

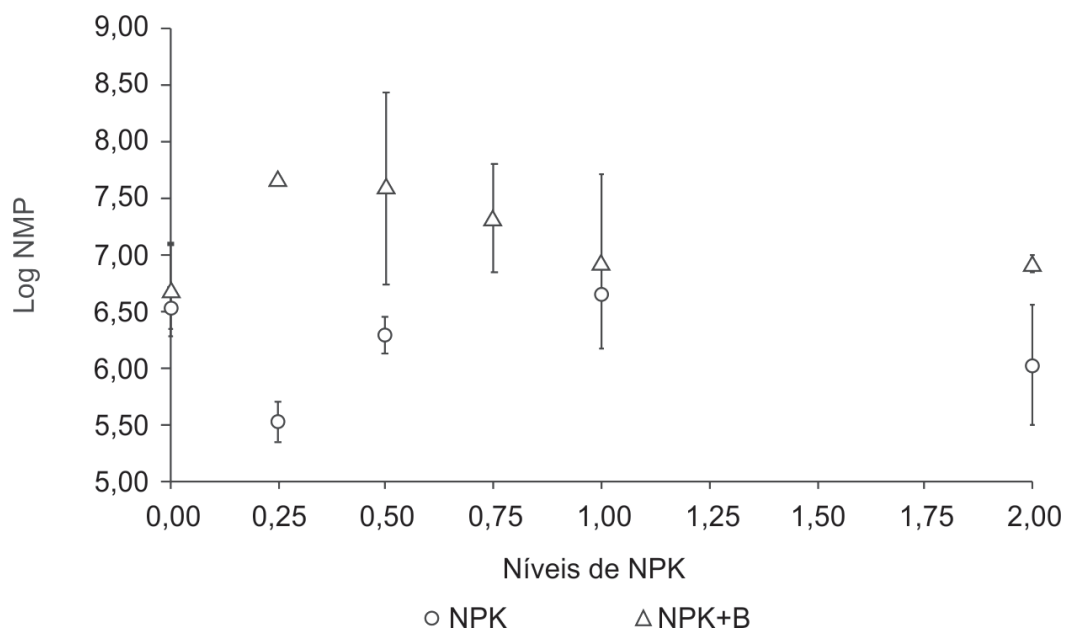

Figure 1. Bacterial populations (log NMP) present in maize roots 30 days after emergence, in response to the levels of NPK with or without inoculation of bacteria Herbaspirillum seropedicae.

\section{CONCLUSIONS}

The application of mineral fertilizer combined with inoculation with Herbaspirillum seropedicae resulted in greater increases in the characteristics growth of shoots and accumulation of $\mathrm{N}, \mathrm{P}$ and $\mathrm{K}$ in shoots of maize plants when compared with the use of fertilizer only.

The inoculation of Herbaspirillum seropedicae did not influence the accumulation of dry matter of the root system of maize plants fertilized with NPK.

The root/shoot ratio decreased with the application of increasing rates of NPK.
The colonization of diazotrophs in inoculated roots of maize were enhanced with the application of fertilizer at rates between 25 and $75 \%$ of the NPK recommended dose.

\section{REFERENCES}

Alvarez V VH \& Ribeiro AC (1999) Calagem. In: Ribeiro AC, Guimarães PTG \& Alvarez V VH (Eds.) Recomendação para o uso de corretivos e fertilizantes em Minas Gerais: 5a Aproximação. $5^{\text {a }}$ ed. Viçosa, Comissão de Fertilidade do Solo do Estado de Minas Gerais. p.52-69.

Alvarez V VH \& Alvarez GAM (2006) Comparações de médias ou testes de hipóteses e contrastes. Boletim Informativo da Sociedade Brasileira de Ciência do Solo, 31:24-34. 
Baldani JI, Teixeira KRS, Schwab S, Olivares FL, Hemerly AS, Urquiaga S, Reis VM, Nogueira EM, Araújo JLS, Borges LE, Soares LHB, Vinagre F, Baldani VLD, Carvalho TLG, Alves BJR, James EK, Jantalia CP, Ferreia PCG, Vidal MS \& Boddey RM (2009) Fixação biológica de nitrogênio em plantas da família Poaceae (antiga Gramineae). In: Ribeiro MR, Nascimento CWA, Ribeiro Filho MR \& Cantalice JRB (Eds.) Tópicos em ciência do solo. Viçosa, Sociedade Brasileira de Ciência do Solo. p.204-271.

Baldotto LEB \& Olivares FL (2008) Phylloepiphytic interaction between bacteria and different plant species in a tropical agricultural system. Canadian Journal of Microbiology, 54:918931

Baldotto LEB, Baldotto MA, Viana AP, Olivares FL \& BressanSmith R (2010) Seleção de bactérias promotoras de crescimento no abacaxizeiro (Ananas comosus L. Merril) cultivar vitória durante a aclimatização. Revista Brasileira de Ciência do Solo, 34:349-360.

Baldotto LEB, Olivares FL \& Bressan-Smith R (2011) Structural interaction between GFP-labeled diazotrophic endophytic bacterium Herbaspirillum seropedicae RAM10 andpineappleplantlets 'Vitória'. Brazilian Journal of Microbiology, 42:114-125.

Brasil (2012) Ministério da Agricultura Pecuária e Abastecimento: Companhia Nacional de Abastecimento. Levantamento de safra brasileira de grãos. Disponível em: <http://www.conab.gov.br/ >. Acessado em: 20 de março de 2012.

Bucher CA \& Reis VM (2008) Biofertilizante contendo bactérias diazotróficas. Seropédica, Embrapa Agrobiologia. 17p. (Documentos, 247).

De-Polli E, Almeida DL, Santos GA, Cunha LH, Freire LR, Amaral Sobrinho NM, Pereira NN, Eira PA, Bloise RM \& Salek RC (1988) Manual de adubação para o estado do Rio de Janeiro. Itaguaí, Editora Universidade Rural. 179p.

Dobbelaere S, Croonenborghs A, Trys A, Vande Broek A \& Vanderleyden J (1999) Phytostimulatory effect of Azospirillum brasilense wild type and mutant strains altered in IAA production on wheat. Plant and Soil, 212:155-164.

Döbereiner J, Baldani VLD \& Baldani JI (1995) Como isolar e identificar bactérias diazotróficas de plantas não-leguminosas. Seropédica, Embrapa Agrobiologia. 66p.

Dotto AP, Lana MC, Steiner F \& Frandoloso JF (2010) Produtividade do milho em resposta à inoculação com Herbaspirillum seropedicae sob diferentes níveis de nitrogênio. Revista Brasileira de Ciências Agrárias, 5:376-382.
Hallmann J, Quaddt-Halmann A, Mahaffeee WF \& Kloepper JW (1997) Bacterial endophytes in agricultural crops. Canadian Journal of Microbiology, 43:895-914.

Hungria M, Franchini JC, Campo RJ \& Graham PH (2005) The importance of nitrogen fixation to soybean cropping in South America. In: Werner D \& Newton WE (Eds.) Nitrogen fixation in agriculture: forestry ecology and environment. Dordrecht, Kluwer Academic Publishers. p.25-42.

Novais RF \& Mello JWV (2007) Relação solo-planta. In: Novais RF, Alvarez V VH, Barros NF, Fontes RLF, Cantarutti RB \& Neves JCL (Eds.) Fertilidade do solo. Viçosa, Sociedade Brasileira de Ciência do Solo. p.133- 204.

Pedrinho EA, Galdiano Júnior RF, Campanharo JC, Alves LMC \& Lemos EGM (2010) Identificação e avaliação de rizobactérias isoladas de raízes de milho. Bragantina, 69:905-911.

Radwan TEL-S, Mohamed ZK \& Reis VM (2004) Efeito da inoculação de Azospirillum e Herbaspirillum em plântulas de milho e arroz. Pesquisa Agropecuária Brasileira, 39:987-994.

Reis VM, Alves GC, Marriel IE, Reis Júnior FB \& Zilli JE (2009) Recomendação de inoculante para a cultura de milho utilizando a bactéria Herbaspirillum seropedicae, estirpe BR 11417. Seropédica, Embrapa Agrobiologia. 2p. (Comunicado Técnico, 119).

Roesch LFW (2007) Diversidade de bactérias diazotróficas endofíticas associadas a plantas de milho. Revista Brasileira de Ciência do Solo, 31:1367-1380.

Rodriguez H \& Fraga R (1999) Phosphate solubilizing bacteria and their role in plant growth promotion. Biotechnology Advences, 17:319-339.

Rothballer M, Eckert B, Schimd M, Fekete A, Schloter M, Lehner A, Pollmann S \& Hartmann J (2008) Endophytic root colonization of gramineous plants by Herbaspirillum frisingense. FEMS Microbiology Ecology, 66:85-95.

Silva FC (2009) Manual de análises químicas de solos, plantas e fertilizantes. $2^{a}$ ed. Brasília, Embrapa Informação Tecnológica. $627 \mathrm{p}$.

Urquiaga S, Cruz HKS \& Boddey RM (1992) Contribution of nitrogen fixation to sugar cane: nitrogen 15 and nitrogen balance estimates. Soil Science Society of America Journal, 56:105-114. 